\title{
The Effect of Future Orientation and Financial Literacy on Family Retirement Planning Mediated by Saving Attitude
}

\author{
Muhammad Arfan Hajam \\ Department of Magister Management, STIE Perbanas Surabaya, Surabaya, 60118 \\ muhammadarfanhajam@gmail.com
}

Received: 06/10/2020.

Reviewed: $10 / 12 / 2020$.

Published: $31 / 12 / 2020$.

Copyright $\odot 2020$ by the author (et al) and Jurnal Sosial Humaniora (JSH)

*This work is licensed under the Creative Commons Attribution International License (CC BY 4.0). http://creativecommons.org/licenses/by/4.0/

(c) () Open Access

\begin{abstract}
Subject Area : Management
Abstract

One of the ways to plan for a retirement plan is by setting a part of the income or funds owned for future life purposes. Retirement planning for families is carried out so that the finances remain stable when entering retirement. This research aims to determine the effect of future orientation and financial literacy on family retirement planning is mediated by saving attitude. The sample in the research is families in the city of Surabaya. The data used in this research are the primary results of questionnaires with 200 samples and data analysis techniques using SEM-PLS. The results of this research indicate future orientation and financial literacy has a positive effect on family retirement planning and been mediated by saving attitude in city of Surabaya.
\end{abstract}

Keywords: Future Orientation; Financial Literacy; Saving Attitude; Retirement Planning

\section{Introduction}

The industrial revolution 4.0 which is marked by digitalization, automation, and artificial intelligence makes everything in human life turn into a digital, completely automated, and information is so easy to find it. It will have influence on people's lifestyles that will depend on technology so that the cost of one's life in the future will require quite a high cost. According to data from the(Central Statistics Agency of the Republic of Indonesia, 2019), the Human Development Index in 2018 reached 71.39, an increase of 0.63 points compared to 2010 which was recorded at 66.53 with an average annual growth of 0.88 percent. In addition, Central Statistics Agency also released the life expectancy of Indonesia where in 2010 when someone was born in Indonesia, the life expectancy of Indonesia rate was 69.81 years and in 2018 an increase of 71.20 years with a life expectancy growth of 0.19 percent. It makes a person need to do a careful retirement planning from an early age, so that they can happily live retirement as at a productive age because the cost of living will increase in retirement and the life expectancy of a person is getting longer and health factors that decline in line with increasing age.

Retirement planning is at least able to provide financial solutions in the future. There are various ways that someone can do to retirement planning, but the main thing is to have a plan about how to retire later. How to save a little at a time is the easiest way to do retirement planning compared to other methods. Retiring from work as an employee does not mean that someone stops working and stops productive because there is no one in this world who just wants to be quiet and not do anything at all. (Moorthy et al., 
2012) revealed that the younger the age of workers ranging from 26-35 years, the greater the possibility that these workers have a better perspective and behavior in planning for retirements early on, because workers have plenty of free time to prepare for retirement with prosperity. It can be interpreted that retirement will be better if someone plans to retire as early as possible, to have a good financial condition at retirement and can plan productive activities in retirement later.

Future orientation is an important factor in retirement planning because it is a stable personality characteristic and it has a significant influence on the outcome of a behavior (Zimbardo \& Boyd, 1999). Future orientation has been described the extent to which future consequences can affect an action when someone makes the decision to plan a retirement. Future orientation is a complex motivational cognitive phenomenon, which is the anticipation and evaluation of someone in the future in their interactions with the surrounding environment. In addition, future orientation is closely related to expectations, goals, standards, plans, and strategies for achieving future goals. (Howlett, Kees, \& Kemp, 2008)suggest that financial knowledge and future orientation can also interact to influence the likelihood of encouraging someone to participate in a retirement program. (Jacobs-Lawson \& Hershey, 2005) also suggested that someone's future orientation influences the behavior of retirement planning which aims to make a person have savings in retirement. A person with a future orientation will be more likely to participate in retirement planning.

Another factor influencing retirement planning is financial literacy. (Van Rooij, Lusardi, \& Alessie, 2011) revealed that financial literacy influences retirement planning. The same thing also stated by (Lusardi $\&$ Mitchell, 2014) revealed that financial literacy can improve the welfare of someone who is directly related to financial knowledge. (Fornero \& Monticone, 2011) suggested that financial literacy influences community participation in retirement planning. (Nejati, Ahmadi, \& Lali, 2015) suggested that financial literacy has a positive influence on family participation in retirement planning. Other opinions were also expressed by (Kholilah \& Iramani, 2013) suggesting that financial knowledge is the basis of critical factors in financial decision making. Someone who has good financial literacy will have a greater tendency in retirement planning. This was also stated by (Selvadurai, Kenayathulla, \& Siraj, 2018) that the higher the financial literacy education one has, the higher one's participation in retirement planning.

In addition, the factor of someone's saving attitude also affects someone in planning their retirements. (Brandstätter, 2005) suggests that someone who has a personality and a high motivation to save, they have tend to set aside some of the income earned for savings. In connection with this, (Payne, Yorgason, \& Dew, 2014) suggested that attitudes towards finances such as saving, it can influence the behavior of a person's retirement planning. The same thing was also stated by (Fazli Sabri \& Tze Juen, 2014) suggesting that saving attitude had a positive influence on the planning of retirements for female workers in Malaysia. (Kimiyagahlam, Safari, \& Mansori, 2019) suggested that there is a positive influence on someone's saving attitude towards retirement planning and there is also a positive influence on saving attitude in mediating future orientation and financial literacy on one's retirement planning. Based on the phenomena found and previous research studies, it makes researchers motivated to study about family retirement planning in city of Surabaya. 


\section{Methodology}

The method in this research is broadly carried out in three stages, namely the survey phase of study I or literature study, survey phase of study II, and the stage of data processing with SEM-PLS which is explained as follows.

\section{Study I}

The survey phase of study I is a stage that reviews from relevant previous research fromnational and international scientific journal articles, and related literature retirement planning that aims to identify the research process. Behavioral planning theory can be used to predict whether a person will or will not perform a behavior. (Ajzen, 1991) explains that attitudes towards a person's behavior are determined by the beliefs obtained about the consequences of a behavior where beliefs are closely related to a person's subjective assessment of the environment and social surroundings.

Research conducted by (Moorthy et al., 2012), entitled "A Study on the Retirement Planning Behavior Of Working Individuals in Malaysia". This study aims to examine the behavior of individuals in Malaysia in planning pension funds. The sample size in this study was 300 respondents with a sampling technique using purposive sampling. The data collection method used a questionnaire. This research uses Multiple Linear Regression analysis techniques. The results in this study reveal that age, education level, income, goal clarity, attitude toward retirement, and potential conflict in retirement have a positive effect on retirement planning. Research conducted by (Payne et al., 2014), entitled "Spending Today or Saving for Tomorrow: The Influence of Family Financial Socialization on Financial Preparation for Retirement". This study aims to examine the influence of materialism, family socialization, anxiety, attitudes to finance, and religiosity on pension fund planning. This research uses the number of respondents as many as 334 respondents. The sampling technique used stratified random sampling and data collection techniques used a questionnaire and data analysis techniques used regression analysis. The results of this study suggest that the attitude variable on finance (saving attitude) has a positive effect on pension fund planning and the variable family socialization, anxiety, and religiosity also has a positive effect on retirement planning, but the materialism variable has a negative effect on retirement planning.

Another research conducted by (Van Rooij et al., 2011), entitled "Financial Literacy and Retirement Planning in the Netherlands". This study aims to examine the effect of financial literacy on pension fund planning in the families of employees of De Nederlandsche Bank in the Netherlands. The data collection technique used a questionnaire with a sample size of 1,508 respondents and the analysis technique used regression analysis. The results of the study found that financial literacy has a positive effect on retirement planning. (Brandstätter, 2005) suggests that one's personality affects someone's saving. Someone who does not have a good retirement plan, tends to spend or spend his money to fulfill consumptive desires. Research conducted by (Kimiyagahlam et al., 2019), entitled "The Effects of Behavioral on Retirement Planning In Malaysia". This study aims to examine people's behavior in planning pension funds in Malaysia. This study uses the SEM-PLS data analysis technique with the results showing that there is a positive influence on future orientation, financial literacy, and saving attitudes on retirement planning and there is a positive effect on saving attitudes in mediating future orientation and financial literacy on retirement planning. 
However, family education and materialism variable have a negative effect on retirement planning. Research conducted by (Selvadurai et al., 2018), entitled "Financial Literacy education and Retirement Planning". This study aims to examine the influence of financial literacy education factors on retirement planning. This research is a qualitative research. In this study, the sampling technique used probabilty sampling to select the research sample and 10 participants were selected from a total of 55 participants who had a good financial literacy education background with data analysis techniques using thematic analysis through interviews for 30 to 80 minutes for each participant (informant).

The results of this study reveal that there is a strong and positive influence on someone who has good financial literacy education in retirement planning. Research conducted by (Nejati et al., 2015), entitled "The Impact of Financial Literacy on Retirement Planning and Household Wealth". This study aims to examine the effect of financial literacy on pension fund planning and family wealth. This study uses data analysis techniques in the form of testing the Pearson correlation coefficient and regression analysis. The results of this study suggest that financial literacy has a positive effect on pension fund planning and family wealth.

Based on a literature review conducted in several studies earlier and phenomena that occur at this time, it motivates researchers to rethink the relationship pattern of future orientation and financial literacy to retirement planning, and savings attitude mediates future orientation and financial literacy in retirement planning and demographic factors moderate financial literacy in retirement planning. The conceptual model of this research is as follows:

Figure 1. Research Conceptual Model

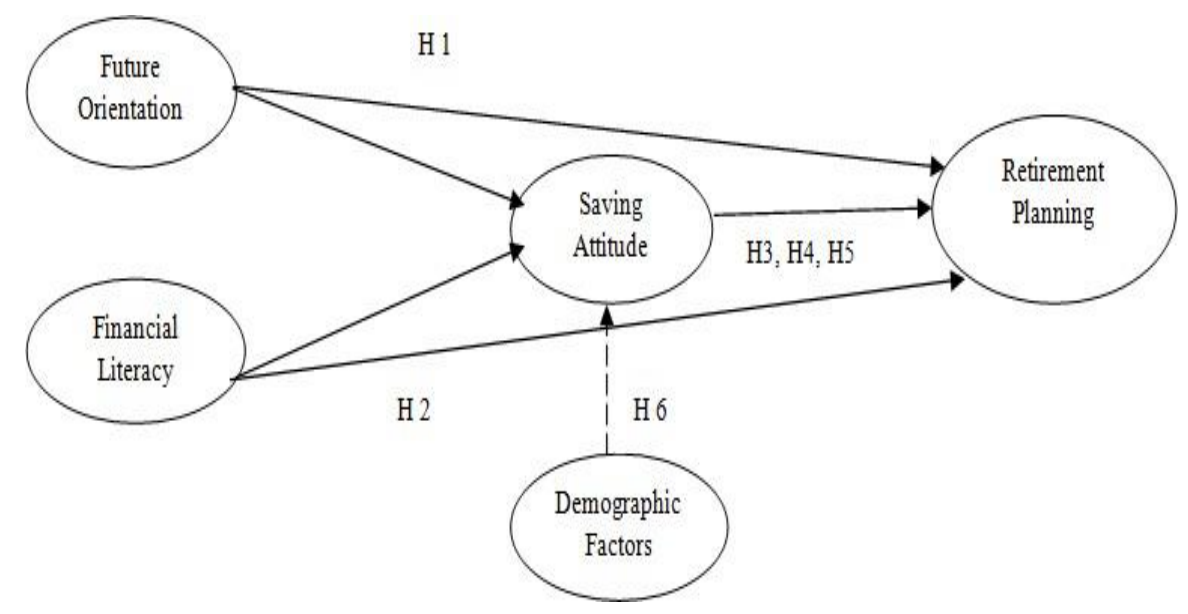

\section{Study II}

The survey phase of study II was carried out through filling out questionnaires by respondents with criteria established by researchers, namely families who live in the city of Surabaya with a minimum income of 6 million rupiahs per month, and already have a retirement program either paid by the company where the respondent works or is paid independently. Sampling technique used purposive sampling. Respondents who were sampled met the criteria set, such as respondents who live in Surabaya and have a minimum income of 6 million rupiah. 
As many as 350 questionnaires have been distributed, there are 140 questionnaires that did not return. The questionnaires which has been filled by the respondent and returned totaled 210 questionnaire, questionnaires are checked and selected according to the criteria of the sample is set. The results of examination and selection on 210 questionnaires showed that there were 10 questionnaires that could not be processed because they did not meet the requirements, so that only 200 questionnaires were eligible and could be further processed using SEM-PLS .

Table 1. Return Rate of the Questionnaire

\begin{tabular}{|l|c|c|}
\hline \multicolumn{1}{|c|}{ Information } & \multicolumn{1}{|c|}{$\begin{array}{c}\text { Questionnaire } \\
\text { Number }\end{array}$} & Percentage \\
\hline Questionnaire distributed & 350 & $(40 \%)$ \\
\hline Questionnaire that did not return & $(140)$ & $(3 \%)$ \\
\hline $\begin{array}{l}\text { Questionnaire that cannot be } \\
\text { processed }\end{array}$ & $(10)$ & $57 \%$ \\
\hline Questionnaire that can be processed & 200 & 5 \\
\hline
\end{tabular}

\section{Data Analysis}

Data processing phase begins with questionnaire data processing using MS Excel and Minitab to obtain descriptive statistics, further processing of data by the method of data analysis techniques Partial Structural Equation Modeling -Least Square (SEM-PLS) was performed using 6.0 WarpPLS software. The choice of the Structural Equation Modeling method is due to the factors that influence the planning of retirements which are difficult variables to measure directly, thus requiring indicators in the measurement process. In addition, the selection of methods using Partial Least Square is used to anticipate data that is not spread normally.

In this research, validity and reliability tests were carried out to measure the structural model regarding the validity and reliability of the data used in this study. The measurement of the validity test uses the loading factor value and the AVE value. The data used is said to be valid if the loading factor indicator value is $<0.05$ and the AVE value is $>0.5$. In addition, the data used is said to be reliable if the Cronbach's Alpha value is $>0.6$ and the composite reliability value obtained is $>0.7$. In this study, testing the outer model using the R-Square coefficients value (coefficient of determination). R-Square coefficients are used to measure how much the endogenous variable is affected by other variables. In this study, hypothesis testing was carried out using the $p$-values significance value and the $\beta$ coefficient value on each path in this research model. The interpretation of the results for hypothesis testing in this study is said to have a significant effect if the significance value of the p-values on each path is $<0.05$ and the coefficient $\beta>0$.

\section{Results and Discussion}

\section{Characteristic Respondents}

The following is a table 2 regarding the characteristics of respondents obtained from questionnaires data. 
Table 2. Characteristics of Respondents

\begin{tabular}{|c|c|c|}
\hline DESCRIPTIVE & TOTAL & PERCENTAGE \\
\hline \multicolumn{3}{|l|}{ Gender } \\
\hline Male & 128 & $64 \%$ \\
\hline Female & 72 & $36 \%$ \\
\hline \multicolumn{3}{|l|}{ Age } \\
\hline 21 to 30 years & 43 & $21.5 \%$ \\
\hline 31 to 40 years & 75 & $37.5 \%$ \\
\hline 41 to 50 years & 66 & $33 \%$ \\
\hline$>50$ years & 16 & $8 \%$ \\
\hline \multicolumn{3}{|l|}{ Education } \\
\hline$\leq$ Middle school & 3 & $1.5 \%$ \\
\hline High school & 28 & $14 \%$ \\
\hline Diploma & 26 & $13 \%$ \\
\hline Bachelor & 133 & $66.5 \%$ \\
\hline Postgraduate & 10 & $5 \%$ \\
\hline \multicolumn{3}{|l|}{ Profession } \\
\hline Civil servants & 16 & $8 \%$ \\
\hline BUMN employee & 35 & $17.5 \%$ \\
\hline Private employee & 86 & $43 \%$ \\
\hline Entrepreneur & 51 & $25.5 \%$ \\
\hline Professional & 12 & $6 \%$ \\
\hline \multicolumn{3}{|l|}{ Monthly income } \\
\hline Rp. $6,000,000$ to Rp. $9,000,000$ & 3 & $1,5 \%$ \\
\hline Rp. $9,000,001$ to Rp. $12,000,000$ & 56 & $28 \%$ \\
\hline Rp. $12,000,001$ to Rp. $15,000,000$ & 87 & $43,5 \%$ \\
\hline Rp. $15,000,001$ to Rp. $18,000,000$ & 39 & $19,5 \%$ \\
\hline > Rp. $18,000,000$ & 15 & $7,5 \%$ \\
\hline \multicolumn{3}{|l|}{ The number of dependents } \\
\hline$\leq 1$ people & 26 & $13 \%$ \\
\hline $2-3$ people & 65 & $32.5 \%$ \\
\hline 4-5 people & 86 & $43 \%$ \\
\hline 6-7 people & 16 & $8 \%$ \\
\hline$\geq 8$ people & 7 & $3.5 \%$ \\
\hline
\end{tabular}


The data that has been selected and fulfills the requirements, tabulates data based on characteristics that include gender, age, education, profession, monthly income, number of dependents, and residential areas in city of Surabaya. The data obtained shows that male respondents as many as 128 respondents and female respondents as many as 72 respondents were dominated by ages between 31 - 40 years as many as 75 respondents. In addition, education level of the average respondents is bachelor as many as 133 respondents with their profession are private employee who average earn 12 million until less than 15 million per month. Most of the respondents live in central Surabaya by having 4-5 dependents. In this research, demographic factors studied are the number of dependents and income per month in a family.

\section{Validity test}

Validity testing uses the AVE value and the loading factor value as an evaluation of the outer model in this study, the validity test can be measured based on the loading factor value $<0.05$ and AVE value $>$ 0.5. The following is the data on the validity of the loading factor is presented in table 3 .

Table 3 Results of the Loading Factor Value

\begin{tabular}{|c|c|c|c|}
\hline Variabel & Indikator & Uji Validitas & Keterangan \\
\hline \multirow{8}{*}{$\begin{array}{c}\text { Future } \\
\text { Orientation }\end{array}$} & FO1 & $<0.001$ & Valid \\
\hline & $\mathrm{FO} 2$ & $<0.001$ & Valid \\
\hline & FO3 & 0.032 & Valid \\
\hline & FO4 & $<0.001$ & Valid \\
\hline & FO5 & $<0.001$ & Valid \\
\hline & FO6 & $<0.001$ & Valid \\
\hline & FO7 & $<0.001$ & Valid \\
\hline & FO8 & $<0.001$ & Valid \\
\hline \multirow{6}{*}{ Saving attitude } & SA1 & $<0.001$ & Valid \\
\hline & SA2 & $<0.001$ & Valid \\
\hline & SA3 & $<0.001$ & Valid \\
\hline & SA4 & $<0.001$ & Valid \\
\hline & SA5 & 0.004 & Valid \\
\hline & SA6 & $<0.001$ & Valid \\
\hline \multirow{9}{*}{$\begin{array}{l}\text { Retirement } \\
\text { Planning }\end{array}$} & RP1 & $<0.001$ & Valid \\
\hline & RP2 & $<0.001$ & Valid \\
\hline & RP3 & $<0.001$ & Valid \\
\hline & RP4 & $<0.001$ & Valid \\
\hline & RP5 & $<0.001$ & Valid \\
\hline & RP6 & $<0.001$ & Valid \\
\hline & RP7 & $<0.001$ & Valid \\
\hline & RP8 & 0.018 & Valid \\
\hline & RP9 & $<0.001$ & Valid \\
\hline $\begin{array}{l}\text { Financial } \\
\text { Literacy }\end{array}$ & FL & No test & No test \\
\hline $\begin{array}{l}\text { Demografi } \\
\text { Factor }\end{array}$ & Demo & No test & No test \\
\hline
\end{tabular}

Based on the results of data processing using WarpPls 6.0, the result is that the significance value of loading factor on all statement items has a value of $<0.05$. This shows that the statement items in the questionnaire are valid and can be used in this study. The following is the data on the validity of the AVE value which is presented in table 4. 
Table 4 Results of the AVE Value

\begin{tabular}{|c|l|l|l|l|l|}
\hline Variabel & \multicolumn{1}{|c|}{ FO } & \multicolumn{1}{|c|}{ SA } & \multicolumn{1}{|c|}{ RP } & \multicolumn{1}{|c|}{ FL } & \multicolumn{1}{|c|}{ Demo } \\
\hline FO & $\mathbf{( 0 . 7 8 8 )}$ & 0.256 & 0.222 & 0.163 & 0.226 \\
\hline SA & 0.256 & $\mathbf{( 0 . 7 1 2 )}$ & -0.129 & 0.022 & -0.086 \\
\hline RP & 0.222 & -0.129 & $\mathbf{( 0 . 5 2 7})$ & 0.540 & 0.513 \\
\hline FL & 0.163 & 0.022 & 0.540 & $\mathbf{( 1 . 0 0 0 )}$ & 0.308 \\
\hline Demo & 0.226 & -0.086 & 0.513 & 0.308 & $\mathbf{( 1 . 0 0 0 )}$ \\
\hline
\end{tabular}

Based on table 4.1, the results of the validity test of the AVE value using SEM PLS showed that the AVE value on all test variables was > 0.5. This shows that the statement items in the questionnaire are valid.

\section{Realibility Test}

Reliability testing in this study using cronbach's value and composite reliability value is an evaluation of the outer model in this study. The reliability of variable data can be said to be reliable if the cronbach's alpha value obtained is $>0.6$ and the composite reliability value is $>0.7$ and can be used in this study. The following is the data on the results of the cronbach's alpha value test and the composite reliability value which is presented in Table 5 .

Table 5 Results of the Composite Reliability and Cronbach's Alpha

\begin{tabular}{|l|c|c|c|c|c|}
\hline \multicolumn{1}{|c|}{ Reliability } & FO & SA & RP & FL & Demo \\
\hline Composite Reliability & 0.893 & 0.734 & 0.727 & 1 & 1 \\
\hline Cronbach's Alpha & 0.814 & 0.613 & 0.604 & 1 & 1 \\
\hline
\end{tabular}

Based on table 5, it shows the results of the statement item reliability testing resulting in a cronbach's alpha value $>0.6$ and a composite reliability value $>0.7$, which means that the variable data is reliable to be used in this study.

\section{Testing Hypothesis}

The following are the results of hypothesis testing using the Partial Least Square (PLS) method using the WarpPLS 6.0 test, which is known the value of each variable in this study which includes future orientation, financial literacy, saving attitude, demographic factors, and planning retirement. The following is the data on the result hypothesis testing which is presented in figure 2. model estimation results. Figure 2 is a summary of the model estimation table for path coefficients and p-values. 
Figure 2. Model Estimation Results

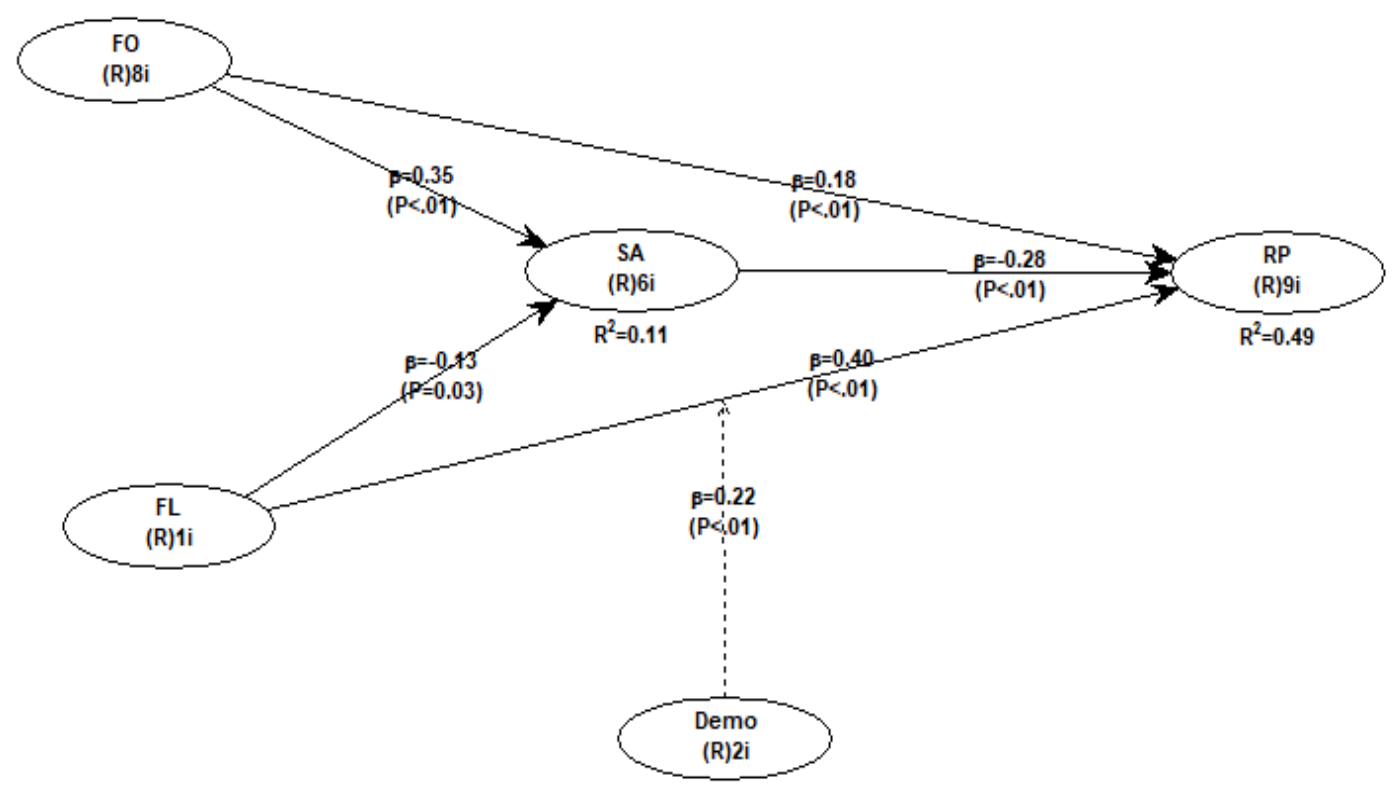

Table 6. Path Coefficients And P- Values

\begin{tabular}{|l|c|c|c|c|}
\hline \multicolumn{1}{|c|}{ Information } & $\begin{array}{c}\text { Coefficient } \\
\text { Value } \beta\end{array}$ & $\begin{array}{c}\text { Expected } \\
\text { Direction }\end{array}$ & p- values & Test result \\
\hline $\mathrm{FO} \rightarrow \mathrm{RP}$ & 0.18 & + & $<0.01$ & H1 Accepted \\
\hline $\mathrm{FO} \rightarrow \mathrm{SA}$ & 0.35 & + & $<0.01$ & H2 Accepted \\
\hline $\mathrm{FL} \rightarrow \mathrm{SA}$ & 0.13 & + & 0.03 & H3 Accepted \\
\hline $\mathrm{FL} \rightarrow \mathrm{RP}$ & 0.40 & + & H4 Accepted \\
\hline $\mathrm{SA} \rightarrow \mathrm{RP}$ & 0.28 & + & $<0.01$ & H5 Accepted \\
\hline $\mathrm{DEMO} \rightarrow \mathrm{FL}, \mathrm{RP}$ & 0.22 & + & $<0.01$ & H6 Accepted \\
\hline
\end{tabular}

Table 7. R - Square Coefficients

\begin{tabular}{|l|l|l|}
\hline Information & R-square & Information \\
\hline SA & 0.11 & FO and FL have an influence on SA by $10 \%$ \\
\hline RP & 0.49 & FO, FL, and SA have an influence on RP by $49 \%$ \\
\hline
\end{tabular}

Based on figure 2. model estimation results can be explained about the results of testing the hypothesis as following.

1. Future orientation has a significant positive effect on retirement planning. 
Based on the first hypothesis and figure 2, the estimation results of the model on a set of future orientation variables indicate that $\mathrm{H} 0$ is rejected or $\mathrm{H} 1$ is accepted. Future orientation has a significant positive effect on retirement planning. This is evidenced by the $\beta$ coefficient of 0.18 and a significant $\mathrm{p}$ - values of $<0.01$ or less than 0.05 . This can be interpreted that the higher the orientation of a person's future, the higher the planned retirement. This shows that the better the future orientation of the family towards more planned family retirement planning.

2. Financial literacy has a significant positive effect on retirement planning.

Based on the first hypothesis and figure 2, the estimation results of the model on the financial literacy variable indicate that $\mathrm{H} 0$ is rejected or $\mathrm{H} 2$ is accepted. Financial literacy has a significant positive effect on retirement planning. This is evidenced by the coefficient $\beta$ value of 0.22 and a significant $\mathrm{p}$ - values of 0.03 or less than 0.05 . This can be interpreted that the higher the financial literacy a person has, the higher the plan for retirements. This shows that the higher the financial literacy of the family towards more planned family retirement planning.

3. Savings attitude mediates future orientation in retirement planning.

Based on the third hypothesis and figure 2, the estimation results of the model on the saving attitude variable mediate the future orientation towards retirement planning showing that $\mathrm{H} 0$ is rejected or $\mathrm{H} 3$ is accepted. Based on the results of the acceptance criteria of mediation variables it can be explained that the attitude of saving mediates partially from the effect of future orientation on retirement planning. This is caused by the relationship of the influence of the three variables that have a significant positive effect on each other as evidenced by the $\beta$ coefficient of 0.35 and the pvalues of $<0.01$ or less than 0.05 . This can be interpreted that the higher the orientation of the future owned by someone and encouraged by a high attitude of saving, the higher the plan for retirement funds. This shows that a good saving attitude will mediate a good future orientation towards more planned family retirement planning.

4. Savings attitude mediates financial literacy in retirement planning.

Based on the fourth hypothesis and figure 2, the results of the model estimation on the saving variable attitude mediate financial literacy towards retirement planning showing that $\mathrm{H} 0$ is rejected or $\mathrm{H} 4$ is accepted. Based on the results of the acceptance criteria of mediation variables it can be explained that the attitude of saving mediates partially the effect of financial literacy on retirement planning. This is caused by the relationship of the influence of the three variables that have a significant positive effect on each other as evidenced by the $\beta$ coefficient of 0.13 and the $p$ - value of $<0.01$ or less than 0.05 . This can be interpreted that the higher the financial literacy a person has and is also encouraged by a high saving attitude, the higher the plan for retirement funds. This shows that a good saving attitude will mediate high financial literacy towards more planned family retirement planning. 
5. Savings attitude has a significant positive effect on retirement planning.

Based on the fifth hypothesis and figure 2, the estimation results of the model on the financial literacy variable indicate that $\mathrm{H} 0$ is rejected or $\mathrm{H} 5$ is accepted. Savings attitude has a significant positive effect on retirement planning. This is evidenced by the coefficient $\beta$ value of 0.28 and a significant $\mathrm{p}$ - value of $<0.01$ or less than 0.05 . This can be interpreted that the higher the saving attitude a person has, the higher the plan for retirements. This shows that a good saving attitude will make family retirement planning more planned.

6. Demographic factors moderate financial literacy in retirement planning.

Based on the sixth hypothesis and figure 2, the results of the model estimation on the set of demographic factors moderate the financial literacy of the retirement planning indicating that $\mathrm{H} 0$ is rejected or $\mathrm{H} 6$ is accepted. Based on the results of the acceptance criteria for moderation variables, it can be explained that demographic factors partially influence the effect of financial literacy on retirement planning. This is caused by the relationship of the influence of the three variables that have a significant positive effect on each other as evidenced by the $\beta$ coefficient of 0.22 and a significant $\mathrm{p}$ - value of $<0.01$ or less than 0.05 . This can be interpreted that the higher the income and the number of dependents (demographic factors) a person and have high financial literacy will influence high retirement planning. This shows that demographic factors reinforce the influence of high financial literacy on increasingly planned family retirement planning.

Mediation variable analysis is obtained through the results of examining the $\beta$ coefficient value by using the sobel test to find out the magnitude of the effect directly or indirectly on the variable being tested. The following is the sobel test results.

Table 8. Sobel Test

\begin{tabular}{|c|c|}
\hline Information & Coefficient Value $\beta$ \\
\hline $\mathrm{FO} \rightarrow \mathrm{RP}$ & 0.18 \\
\hline $\mathrm{FO} \rightarrow \mathrm{SA} \rightarrow \mathrm{RP}$ & $\begin{array}{c}0.35 * 0.28= \\
0.098\end{array}$ \\
\hline $\mathrm{FL} \rightarrow \mathrm{RP}$ & 0.22 \\
\hline $\mathrm{FL} \rightarrow \mathrm{SA} \rightarrow \mathrm{RP}$ & $\begin{array}{c}0.13 * 0.28= \\
0.036\end{array}$ \\
\hline
\end{tabular}

Based on table 4, it can be explained that the influence of future orientation directly has a smaller value compared to the effect of future orientation on retirement planning which is mediated by saving attitude. This can be proven from the coefficient value of $\beta \mathrm{FO} \rightarrow \mathrm{RP}$ of 0.18 while the coefficient value of $\beta \mathrm{FO} \rightarrow \mathrm{SA} \rightarrow$ RP of 0.098. Besides the direct influence of financial literacy also has a smaller value compared to the effect of financial literacy on retirement planning which is mediated by saving attitude which can be proven from the coefficient value of $\beta \mathrm{FL} \rightarrow \mathrm{RP}$ of 0.22 while the coefficient value of $\beta \mathrm{FL} \rightarrow \mathrm{SA} \rightarrow \mathrm{RP}$ of 0.036 . This 
can be interpreted that the effect of the variable directly has a smaller value than the effect of the mediated variable. Based on the results of the above research, future orientation and financial literacy have a positive effect on retirement planning which is mediated by the attitude of saving to families in the city of Surabaya. When a family has good financial literacy, the family will be able to plan a good retirement. In addition, families with a future orientation will tend to have good pension plans. Families who have a future orientation and good financial literacy will be able to make the family plan a retirement that aims to keep financials stable when entering retirement. Besides that, a good saving attitude factor can mediated by future orientation and good financial literacy in the family to plan their pension as early as possible. It is due to families who have a high saving attitude will tend to set aside a portion of the income they have for saving which aims to meet future life needs so that families who have a high saving attitude will tend to have a future orientation and good financial literacy due to the family constantly striving to find financial information on an ongoing basis to be able to manage family finances appropriately.

The interpretation of the hypothesis test results is that a family with a good future orientation will make the family pension fund planning more planned. In addition, families who have a high level of literacy will make the family more planned in planning the family pension fund. Demographic factors will strengthen the influence of family financial literacy on planning for pension funds that are increasingly well-planned, and a good saving attitude owned by a family will mediate a family with high financial literacy and a good future orientation to be more planned in planning retirement funds.

\section{Conclusions}

The results of this study shows that families who have already retirement planning tend to have a future orientation in their lives and have high financial literacy supported by the habit of saving a portion of their income each month. Family income above the minimum wage in the city of Surabaya will tend to have a greater chance of setting aside income each month which has a positive impact on future orientation. Provision for part of the income to the family will be made after meeting the needs of life for all family members. This can be interpreted that the number of dependents in a family will have an impact on the allowance for income set aside each month. However, families that have many dependents will tend to be careful in the use of money that has a positive impact on increasing the family's financial literacy so that families with more dependents will tend to have high financial literacy because the family will look for information about using money appropriately.

This research is in accordance with previous research. The result of this study is show that a family with a good future orientation will make the family pension fund planning more planned. In addition, families who have a high level of literacy will make the family more planned in planning the family pension fund. Demographic factors will strengthen the influence of family financial literacy on planning for pension funds that are increasingly well-planned and also a good saving attitude owned by a family will mediate a 
family with high financial. Based on the estimation results of the WarpPLS 6.0 model in Figure 2, it shows that the R-square value is 0.49 or $49 \%$, which means there is still $51 \%$ influence from other variables that can affect pension fund planning.

\section{References}

Ajzen, I. (1991). The theory of planned behavior, v. 50, n. 2, p. 179-211, 1991. Organizational Behavior and Human Decision Processes.

Brandstätter, H. (2005). The personality roots of saving - Uncovered from German and dutch surveys. In Consumers, Policy and the Environment A Tribute to Folke Ölander. https://doi.org/10.1007/0-38725004-2_4

Central Statistics Agency of the Republic of Indonesia. (2019). No Title.

Fazli Sabri, M., \& Tze Juen, T. (2014). The influence of financial literacy, saving behaviour, and financial management on retirement confidence among women working in the Malaysian public sector. Asian Social Science. https://doi.org/10.5539/ass.v10n14p40

Fornero, E., \& Monticone, C. (2011). Financial literacy and pension plan participation in Italy. Journal of Pension Economics and Finance. https://doi.org/10.1017/S1474747211000473

Howlett, E., Kees, J., \& Kemp, E. (2008). The role of self-regulation, future orientation, and financial knowledge in long-term financial decisions. Journal of Consumer Affairs. https://doi.org/10.1111/j.1745-6606.2008.00106.x

Jacobs-Lawson, J., \& Hershey, D. (2005). Influence of Future Time Perspective, Financial Knowledge, and Financial Risk Tolerance on Retirement Saving Behaviors. Financial Services Review.

Kholilah, N. Al, \& Iramani, R. (2013). STUDI FINANCIAL MANAGEMENT BEHAVIOR PADA MASYARAKAT SURABAYA. Journal of Business and Banking. https://doi.org/10.14414/jbb.v3i1.255

Kimiyagahlam, F., Safari, M., \& Mansori, S. (2019). Influential Behavioral Factors on Retirement Planning Behavior: The Case of Malaysia. Journal of Financial Counseling and Planning. https://doi.org/10.1891/1052-3073.30.2.244

Lusardi, A., \& Mitchell, O. S. (2014). The economic importance of financial literacy: Theory and evidence. Journal of Economic Literature. https://doi.org/10.1257/jel.52.1.5

Moorthy, M. K., Chelliah, T. D. a/l, Sien, C. S., Leong, L. C., Kai, N. Z., Rhu, W. C., \& Teng, W. Y. (2012). A Study on the Retirement Planning Behaviour of Working Individuals in Malaysia. International Journal of Academic Research in Economics and Management Sciences, Vol. 1, No, 54.

Nejati, F., Ahmadi, M., \& Lali, M. (2015). The Impact of Financial Literacy on Retirement Planning and Household Wealth. Indian Journal of Fundamental and Applied Life Sciences ISSN:

Payne, S. H., Yorgason, J. B., \& Dew, J. P. (2014). Spending Today or Saving for Tomorrow: The Influence of Family Financial Socialization on Financial Preparation for Retirement. Journal of Family and Economic Issues. https://doi.org/10.1007/s10834-013-9363-2

Selvadurai, V., Kenayathulla, H. B., \& Siraj, S. (2018). Financial literacy education and retirement planning 
in Malaysia. Malaysian Online Journal of Educational Management. https://doi.org/10.22452/mojem.vol6no2.3

Van Rooij, M. C. J., Lusardi, A., \& Alessie, R. J. M. (2011). Financial literacy and retirement planning in the Netherlands. Journal of Economic Psychology. https://doi.org/10.1016/j.joep.2011.02.004

Zimbardo, P. G., \& Boyd, J. N. (1999). Putting time in perspective: A valid, reliable individual-differences metric. Journal of Personality and Social Psychology. https://doi.org/10.1037/0022-3514.77.6.1271 